REVIEW OF HISTORICAL SCIENCES 2017, VOL. XVI, NO. 3

http://dx.doi.org/10.18778/1644-857X.16.03.02

Matgorzata Karkocha

UnIVERSity OF LODZ*

\title{
The Russo-Turkish war (the campaign of 1789) in the light of reports from "Pamiętnik Historyczno-Polityczno-Ekonomiczny"
}

Summary. The subject of the article is the Russo-Turkish war of 1787-1792, more precisely the campaign of 1789. The issue will be discussed basing on the information published in "Pamiętnik Historyczno-Polityczno-Ekonomiczny". The journal was coming out in Warsaw in the years 1782-1792, and Piotr Switkowski was its editor and publisher. Since the beginning of the Russo-Turkish war, which Austria joined as Catherine II's ally in February 1788, "Pamiętnik" was posting periodic reports on the activities at the Turkish front. It described the most important battles as well as less significant skirmishes, informed on the movements and the status of the fighting armies, printed the war complements and biographical notes of military commanders. As a supporter of pro-Turkish politics, Switkowski spoke of the Ottoman Porte and inhabitants of Turkey with fondness, praised the bravery of a Turkish soldier, and positively reflected on the military reforms in that country.

Keywords: Russo-Turkish war 1787-1792, campaign of 1789, "Pamiętnik Historyczno-Polityczno-Ekonomiczny", Piotr Świtkowski, Warsaw press, $18^{\text {th }}$ century.

$\mathrm{P}$ amiętnik Historyczno-Polityczno-Ekonomiczny" was a monthly edited by ex-Jesuit, Father Piotr Świtkowski (1744-1793) ${ }^{1}$. The journal was published in the years $1782-1792$ in the capital

* The Faculty of Philosophy and History, The Institute of History, The Department of Modern History / Wydział Filozoficzno-Historyczny, Instytut Historii, Katedra Historii Nowożytnej, e-mail: malkarkocha@o2.pl.

${ }^{1}$ On Świtkowski's life as well as his writing and publishing activity, see E. Aleks androwska, Świtkowski Piotr, [in:] Dawni pisarze polscy od poczatków piśmiennictwa do Młodej Polski. Przewodnik biograficzny i bibliograficzny, vol. IV (S-T), ed. R. Loth, Warszawa 2003, pp. 232-233; I. Ło s s ow s ka, Piotr Świtkowski 
of the Commonwealth under a repeatedly changed title: in 1782 and 1783 as "Pamiętnik Polityczny i Historyczny, dziejów, ustaw, osób, miejsc i pism wiek nasz szczególniej interesujących", since 1784 as "Pamiętnik Historyczno-Polityczny przypadków, ustaw, osób, miejsc i pism wiek nasz szczególniej interesujących", and finally since 1788 as "Pamiętnik Historyczno-Polityczno-Ekonomiczny przypadków, ustaw, osób, miejsc i pism wiek nasz szczególniej interesujacych". The paper was printed in His Majesty's printing house, in a small 16 mo format. The volume of each publication was approx. eighty pages, and during the time of the Great Diet exceeded one hundred pages. "Pamiętnik" was a journal of socioeconomic character, but also included in its columns the information on the latest world affairs ${ }^{2}$.

The layout of individual issues remained mostly fixed. The first article was a record of international travels, followed by an account on the lives of prominent statesmen and leaders, which were based on the foreign-language sources. Next, there was a review of international political affairs which discussed: the course of armed conflicts, the distribution of power within particular countries, diplomatic moves of monarchs. Subsequent articles referred to the Polish matters, many of which dealt with trade, industry and agriculture. The permanent section entitled $A$ political picture of various countries (also: A history of various countries and A political picture of Europe) contained up-to-date news from abroad and, at times, also from the country. Since 1787, at the end of each issue, if there was enough space left, Switkowski added the section New inventions, fine craftsmanship. It was meant to provide information on the latest scientific achievements, the deaths of distinguished scientists, the rulers' actions on the acceleration of trade and agriculture as well as on the improvements in the educational system, and pieces of practical advice.

(1744-1793), [in:] Pisarze polskiego Oświecenia, eds T. Kostkiewiczowa, Z. Goliński, vol. II, Warszawa 1994, pp. 305-319; I. Homola-Dzikowska, Pamiętnik Historyczno-Polityczny Piotra Świtkowskiego 1782-1792, Kraków 1960, pp. 10-24.

${ }^{2}$ For this reason, Switkowski was subject to persecution by Father Stefan Łuskina, the editor of "Gazeta Warszawska", who engaged himself into fierce polemics against Świtkowski and even filed a lawsuit against him over breaking the monopoly on publishing newspapers in the capital. For more details, see J. Łoj ek, "Gazeta Warszawska” księdza Euskiny (1774-1793), Warszawa 1959, pp. 75-79; J. Bartoszewicz, Gazeta księdza Łuskiny, [in:] id e m, Znakomici mężowie Polscy $w$ XVIII $w$., vol. I, St. Petersburg 1855, pp. 304-309. 
The political reports from abroad published in "Pamiętnik" constituted extensive summaries of articles from foreign journals. Świtkowski used mainly French, Italian, English and, most of all, German newspapers as he was fluent in the German. His subscriptions included, for instance: "Mercure de France", "Journal de Paris", so called "Hamburg Gazette" ("Staats und Gelehrte Zeitung des Hamburgischen Unpartheyischen Correspondenten") and "Journal d'Atlona". The author translated selected news himself or commissioned the work to someone else, and later featured them in "Pamiętnik". In addition to extensive extracts from foreign books and papers of German economists (Schubart, among others), he included works submitted by readers, some of which took form of the so-called letters to the editor ${ }^{3}$.

Since the outbreak of the Russo-Turkish war, each month Switkowski posted articles discussing the course of the conflict ${ }^{4}$. He reported on activities on the ground and the sea, on the movements and status of the fighting armies, described the most important battles and minor skirmishes, printed the war complements, quoted statistical, geographical and biographical information. He also informed on the efforts made by European courts to restore peace. It should be noted that the editor of the "Pamietnik" was a proponent of pro-Turkish politics, which affected the content of the information provided. Switkowski demonstrated his linking for Turkey and the Turks, praised the courage and gallantry of Ottoman soldiers, and also made attempts at demonstrating that the Sublime Porte was not as "eaten away" by the internal decay as it was commonly believed ${ }^{5}$.

${ }^{3}$ For more information on the journal, see I. Homola-Dzikowska, op. cit., passim; also: W. Giełżyński, Prasa warszawska 1661-1914, Warszawa 1962, pp. 45-50; M. Karkocha, Obraz Francji $w$ dobie rewolucji na łamach prasy warszawskiej z lat 1789-1794, Łódź 2011, pp. 51-62; J. Łoj ek, Historia prasy polskiej, Warszawa 1976, pp. 50-52; idem, Dziennikarze i prasa $w$ Warszawie w XVIII wieku, Warszawa 1960, p. 94 and the following.

${ }^{4} \mathrm{He}$ also wrote about it frequently in the section: A political picture of various countries.

${ }^{5}$ For example, in July 1788 , comparing the military forces of Turkey and of the allied empires, the priest wrote: "Before this war began, the opinions about the Turkish army were mistaken and essentially false. Public magazines depicted their army as a group of innumerable, weak men, who are willful, defenseless, and exercise neither discipline nor combat, and have no knowledge of warfare. They assured that once the Turks faced the first defeat or famine, suffered from exhaustion and hardships of war, they would disperse and leave the banners of Muham- 
The war between the Russian and Ottoman Empire began in August 1787. The immediate cause of the break-up of diplomatic relations between the two countries was the meeting of the all-Russian Empress with Joseph II in Kherson in May of the said year, which the Turkish cabinet saw as a provocation. Yet, the real reason was the annexation of Crimea (1783) and placing eastern Georgia under Catherine II's protectorate, as well as other issues of lesser importance ${ }^{6}$, which were infringements of the Treaty of Küçük Kaynarca (1774). The Turks mobilized a mighty army of over two hundred thousand soldiers under the command of Grand Vizier Koca Yusuf Pasha. They also sent most of their fleet to the Black Sea, commanded by Kapudan Pasha Gazi Hasan. The attack from Ochakiv on Kinburn, Kherson and Crimea was planned. Russia, surprised by the course of events, was unprepared for the war. It took several months before the Russian troops (one hundred and twenty thousand soldiers) could mass in the south of the country. The Russian armed forces were divided into two armies: the Ukrainian, under the leadership of Count Pyotr Rumyantsev-Zadunaisky, a veteran of the previous Turkish War, and of Empress Catherina II, under the command of Prince Grigory Potemkin, who

mad behind as quickly as they massed. Such assumptions were based on how the things were in the past. But it has changed. [...] According to an Englishman who has just returned from Constantinople after many years, contrary to a popular belief, the Turks are not ill-prepared for this war. Their guards keep more careful watch, their pickets are arranged in a well-thought-out and cautious way, and their patrol conducts reconnaissance as regularly as in any other European army. Now, they do not run into an ambush as easily as during the past wars. Their artillery, which previously consisted of large equipment that was difficult to move, is now lighter and better constructed, in accordance with the French and English measures". And later: "The Turkish cavalry moves at astonishing speed, never leaving the enemy at peace, charging at the guards, provoking them constantly. The Turkish infantry is also better trained than before..." "Pamiętnik Historyczno-Polityczno-Ekonomiczny" [further on: PHPE], July 1788, pp. 592-595.

${ }^{6}$ Providing shelter to the Prince of Muntenia, Alexandru; preventing the inhabitants of Ochakiv from salt mining in the lakes located between Kinburn and Kobkoi, which they were entitled to for a long time; setting the Turkish subjects against Turkey in Muntenia, Wallachia and the archipelago of the Greek islands; imposing restrictions on the Turkish merchants in Russia, etc. All complaints and matters of argument were included in the manifesto of the Porte of August 1787, submitted to the ministers of foreign courts in Constantinople. The priest-editor mentions it in "Pamiętnik", but does not provide its contents. It was printed in full form by the competitor of Świtkowski's journal, "Gazeta Warszawska" (No. 41-43 of 1788 , no page numbering). 
by the will of the monarch served as the field marshal and grand admiral. The regiments stationed in the Caucasus and Kuban, commanded by General Tökeli, were also at their disposal. The main task of the Russian troops was to take all the coastal fortresses, from Ochakiv to the estuary of the Danube, and by doing so, to connect the Crimean Peninsula, Novorossiya and Bessarabia.

In 1787, the Turks still tried to seize Kinburn, but without much success. Having been defeated twice at the Dnieper Estuary and in Ochakiv (June 18 and 28, 1788), as well as next to the Fidonisi island, east of the Danube delta (July 14, 1788), their fleet retreated to Constantinople. On the land, the grand vizier was reluctant to give up the major battle to the enemy, sending numerous units for hit-and-run attacks. In February 1788, fulfilling his obligation as an ally to Catherine II, Emperor Joseph II declared the war on the Porte. Even though the Austrians did not manage to score a decisive victory, they seized Khotyn in Moldavia and several smaller forts in Bosnia (Dërsnik, Dubica, Novi) and Serbia (Šabac). The Russians were involved in fights but without rushing. Their main goal was to capture the fortress Ochakiv by the Black Sea, which had been taken by a violent assault after many weeks of siege (December 17, $1788)^{7}$. Switkowski wrote extensively on the incident in the February issue of "Pamietnik", pointing to the atrocities of the Russian troops that slayed almost the whole civilian population ${ }^{8}$.

In May 1789, the priest-editor informed about a new campaign on the eastern front, describing the military preparations of the Porte and the first skirmishes and operations. This time, Turkey appeared in the field much earlier than in the previous year and mobilized all the armed forces of its population that counted millions of people. In the winter of $1788 / 89$, numerous troops from all over Asia massed in Constantinople. The built-up army was much

${ }^{7}$ More information on the beginnings of the war and the 1788 campaign, see W. Kalinka, Sejm Czteroletni, vol. I, Warszawa 1991, pp. 28-45; W. M or aw ski, S. Szawłows ka, Wojny rosyjsko-tureckie od XVII do XX wieku, Warszawa 2006, pp. 80-86; J. Gozdawa-Gołębiowski, Wojny morskie 1775-1851, Warszawa 2001, pp. 137-142; P.P. Wieczorkiewicz, Historia wojen morskich. Wiek żagla, vol. I, Warszawa 1995, pp. 406-410; and especially M. Karkocha, Wojna rosyjsko-turecka na łamach "Pamiętnika Historyczno-Politycznego" (1787-1788), [in:] Sic erat in votis. Europa i swiat $w$ czasach nowożytnych. Studia i szkice ofiarowane Profesorowi Zbigniewowi Anusikowi $w$ sześćdziesiata rocznice urodzin, eds M. Karkocha, P. Robak, Łódź 2017, pp. 311-342.

8 PHPE, February 1789, pp. 137-155. 
larger than expected. Instead of eight thousand soldiers demanded by the Imperial Council, Kara Osman Oglu Pasha and the pasha of Armenia raised an army of forty-eight thousand soldiers. The hopes of great looting made the Asians join the army under Muhammad's flags with great enthusiasm and in big numbers. The Turkish fleet was also rebuilt: it consisted of approx. two hundred smaller and larger vessels ${ }^{9}$. Grand Admiral (Kapudan Pasha) Gazi Hassan was planning to take twenty-four thousand soldiers on boats to restore the Ottoman strength as it slightly faltered after the previous campaign. Maintaining a large ground army and navy obviously required adequate financial resources. Hence, the Imperial Council ordered the Ottoman subjects in Europe to bring all their silver utensils, dishes and ornaments to the mint, where they were to be melted down into money ${ }^{10}$. Gazi Hassan was one of the first people to follow the order, while Grand Vizier Koca Jusuf Pasha left for himself only two pairs of the fine horse tack equipment. As the commander-in-chief of the Turkish army, Koca Yusuf Pasha called in the assembly of troops in Wallachia, Bessarabia, Serbia and Bosnia. Already in March and April of 1789, many Turkish troops from Wallachia were conducting raids on Transylvania; each time, however, they were driven away by the imperial army. One such group reached Ocna, slayed a dozen or so of daring men, looted and burnt the town. The same happened with several villages on their way back ${ }^{11}$.

As stated by Świtkowski, Turkey's military activities and preparations coincided with the demands they presented through the Spanish envoy, who was working hard to restore peace in Europe. The Porte demanded the return of all the lands and fortresses lost during the conflict, in addition to Banat as compensation for the war expenses. The Viennese court responded that since the Sultan was not willing to incur any losses, he would not get anything and the war would continue until it come to an end by itself. This imperial note, sent to Constantinople on March 17, caused considerable stir in the Austrian army and prompted the willingness to

${ }^{9}$ In the previous campaign, the Turkish fleet consisted of eighty different ships. See PHPE, March 1788, p. 237.

10 For each oka of silver, i.e. less than three lbs., the mint paid one hundred piasters. "But since the piaster is only partly made of silver and its face value is hardly half of its intrinsic value, the Porte gains about sixty percent on this operation", wrote Świtkowski. PHPE, May 1789, pp. 503-504.

${ }^{11}$ Ibidem, pp. 501-505. 
immediate fight among the soldiers. However, due to heavy floods, Joseph II's army could not begin military operations and set up a camp until the beginning of May 1789. Another issue the army had to face was an epidemic. The plague took the largest death toll in the Slovak corps, where, in February, one thousand and ninety soldiers of infantry and seventy-nine of the cavalry lost their lives. At the end of the month, five thousand six hundred and nineteen sick people stayed in Croatian quarantine areas, while the Croatian troops totaled a little bit over thirty-five thousand men, which means that the fifth part of the Croatian army was incapable of fighting. A large-scale recruitment in the Austrian countries made up for the losses and at the end of May, all the regiments were rebuilt. Most of the army volunteers came forward in Hungary as they suffered from high prices all over the country and frequently lacked source of income ${ }^{12}$.

The overflowing Danube and Sava and, above all, the severe illness of the emperor delayed the commencement of the campaign on the Austrian side ${ }^{13}$. It wasn't until May that Field Marshal András Hadik von Futak set off to Syrmia (Srem) to take command in the main army, replacing Count Joseph Franz von Lacy ${ }^{14}$. Also, Field Marshal Baron Ernst Gideon von Laudon (Loudon) ${ }^{15}$ led the army of eighty thousand to conquer the Turkish Croatia and Bosnia. The Ottomans, using the setbacks in the camp of the enemy, attempted to invade Joseph II's lands in different areas. The first major attack occurred in Croatia near the Lika Trail. "It might have been damaging to the imperial army", as we read in "Pamiętnik", "if it hadn't been for the cannon fire heard three times which revealed intentions of the Turks, and made the Austrians gather quickly and repel the Ottoman attack at a loss"16. Likewise, the Ottoman troops failed in the second assault in the same area near Przytyn. Another operation, on April 8, in Transylvania, turned out to be of more importance, though still unsuccessful for the Porte. On that day, seven thousand soldiers of the Turkish cavalry and infantry approached

\footnotetext{
12 Ibidem, pp. 505-507.

${ }^{13}$ See C. von Wurzbach, Biographisches Lexikon des Kaiserthums Oesterreich, vol. XIV, Wien 1865, pp. 166-170.

${ }^{14}$ See J. Hirte n feld, Der Militär-Maria-Theresien-Orden und seine Mitglieder: Nach authentischen quellin bearbeitet, Wien 1857, pp. 60-62.

15 See ibidem, pp. 48-57; C. von Wurzbach, op. cit., vol. XVI, Wien 1867, pp. 66-92.

16 PHPE, May 1789, p. 508.
} 
Valli Muliri on the Transylvanian border. They put two hundred Austrian riflemen to flight and stormed towards Dicalu Hontili, where the said riflemen managed to prepare themselves, backed by a few hussar squadrons and five infantry divisions. The emperor's soldiers positioned themselves in a place that was accessible only through a narrow gorge, defended by riflemen and skillfully arranged cannons. The Turkish cavalry broke through the gorge with outstanding bravery and clashed with the Austrians; yet, they could not withstand the attack of artillery, assisted by numerous units of cavalry and infantry. After three hours of fighting, the Turks were forced to retreat, leaving behind two hundred and fifty-three of their soldiers. The Austrians did not sustain severe losses, a dozen men or so were wounded or killed ${ }^{17}$.

Given that the raids were unsuccessful in the area, the grand vizier ordered Serasker Anatoly Haggy Soitary, the commanding officer of a large cavalry corps in Wallachia, to move in towards the troops of Prince Frederick Josias of Saxe-Coburg-Saalfeld ${ }^{18}$, which were stationed near the town of Roman in Muntenia. On April 19, the colonel leading the Austrian vanguard, Count Andreas Karaiczay de Wallje-Szaka, ${ }^{19}$ received a message that a big group of Turkish horsemen was advancing on Bacău on the highroad. And so, he ordered to mobilize his men camping in Faraoani and the surrounding towns and equipped them with cannons. Hardly had Karaiczay given the orders when five thousand sipahis appeared. The Turks crossed the ditch full of water and dashed at the hussars. As the Turkish cavalry outnumbered the Austrians, Colonel Karaiczay called in his horsemen to pull back towards the cannons, which were firing at the enemy time and again. The Turks stopped their initial attack at the Austrian center and directed all their forces at the left flank of the opponent. Nonetheless, the cannonballs and canister shots, along with the brave resistance of the hussars, forced them to retreat. The sipahis reorganized themselves and charged at the center and the right flank of the Austrian corps so forcefully that they reached the infantry and cannons. But the fire of artillery did not let them remain there for too long. Eventually, the Austrians repulsed to the attack of the enemy. The Turks lost in this battle approx. two hundred people and one hundred horses.

\footnotetext{
17 Ibidem, pp. 506-509.

18 See C. von Wurzbach, op. cit., vol. II, Wien 1857, pp. 395-398.

19 See J. Hirtenfeld, op. cit., pp. 293-295.
} 
On the winners' side, the damage amounted to the death of fourteen people and thirteen horses, in addition to thirty-two people and fifty horses that were severely injured. Switkowski concluded: "And here is another proof of what great tactics and discipline can do at war. The Turkish cavalry included five thousand of the finest men and horses, while the Emperor's army had only one thousand and one hundred horsemen and eight hundred and several dozen soldiers on foot. But the short-sighted and foolhardy impulsiveness driven solely by an object of one's desires can do nothing against the infantry formed in square and the tightly-arranged, stumbling cavalry that are led by an experienced commander" ${ }^{20}$. The Austrians also claimed victory over eight thousand Tatars who wanted to pass unnoticed from Muntenia to Bucovina and yet, were noticed and forced to withdraw. In other areas, the Ottomans had a bit more luck. In Croatia, they reduced to ashes the village of Glina and slayed its inhabitants. They also burnt a few villages in Transylvania and made the Austrians retreat from Gura Lotra ${ }^{21}$.

In the further part of the article, the editor of "Pamiętnik" informs that the Russian army "that was almost always launching their military campaigns later than other nations", opened it very early the given year. Changes took place in the empress' army. Field Marshal Pyotr Rumyantsev-Zadunaisky was recalled back to St. Petersburg, while Prince Nikolai Repnin was sent in his place. For seizing Ochakiv, Prince Potemkin was awarded a title of Field Marshall and put in command of both, the army of Catherine and that of Ukraine. The commander-in-chief remained in St. Petersburg until May, not rushing out to get into combat. The Turks assumed that the changes in Catherine II's army might work to their benefit. Therefore, they began gathering in Muntenia and marching towards Jassy. The Turkish army intended to attack the enemy as soon as they would leave the camp in Jassy, where they stationed the whole winter. In anticipation of being assaulted, Lieutenant General Otto Wilhelm Derfelden (Dorfelden) led the corps of a few thousand men against the Turks and attacked them near Măxineni, scattering them all over the place (April 16). Two pashas and several hundred soldiers were brought into captivity. Taking advantage of the defeat of their enemy, the Russians moved into Galați, and despite the courageous defense of the Turkish garrison, the city was taken by

20 PHPE, May 1789, pp. 512-513.

${ }^{21}$ Ibidem, pp. 509-514. 
storm. Hence, launching a new military campaign, the allied troops reached the Danube river, took control of Muntenia and a part of Wallachia. Switkowski states that only by engaging into a major battle, the grand vizier, who camped on the other side of the Danube, could prevent the Russians from overtaking the remaining territory. Also, giving up on Wallachia would inevitably lead to the fall of Bender and the loss of the whole Bessarabia. But at that time, something happened in Constantinople that left grand vizier with his hands tied. On April 7, 1789, Turkish sultan Abdul Hamid I passed away unexpectedly at the age of 64. His son, 28-year-old Selim III, was determined to restore the Ottoman Empire to its former glory and power. The grand vizier had to wait for the orders of the new sultan and watch calmly as the Austrian and Russian troops were advancing on the other side of the Danube ${ }^{22}$.

Opening the June reports on the eastern war, the editor of "Pamiętnik" writes: "Such a great success of the Russian vanguard in Moldavia, and such sudden and persistent assaults of the Turks on various units of the imperial army in Transylvania and Croatia, which followed the excursion of Field Marshals Hadik and Laudon to Hungary and Croatia last month, were a promise of large and important military operations the month we are in. Yet, they turned out to be smaller than expected"23. Knowing that the main Russian army was following him without haste and that the grand vizier was sending his few troops across the Danube river, General Derfelden, who had no more than several thousand soldiers, withdraw from Galați. First, however, he looted and set the city on fire. The Turks immediately overtook the place. While nothing significant happened in Transylvania and Banat, the Ottoman troops were more active on the Croatian border. On May 22, sixteen thousand Ottomans charged at the imperial vanguard camping outside Obergrahovo and crushed it, despite their persistent defense. They dashed to Tubar, where the imperial troops made an unsuccessful attempt to stop them. It was not until they reached Dobrozello that they encountered strong resistance, and after ten hours of fighting, the Croatian troops forced them to pull back. The Turks burnt down a few villages, took several hundred men and women into captivity and killed the rest.

\footnotetext{
${ }^{22}$ Ibidem, pp. 514-517, 548-549. See W. Kalinka, op. cit., p. 474.

${ }^{23}$ PHPE, June 1789, p. 628.
} 
In the later part of the article, Switkowski informs that in the early June 1789, Field Marshal Laudon built up nineteen infantry battalions and ten cavalry squadrons, and led them to the Turkish border. The editor further explains that the Austrian commander's inactivity was due to the issues with supplies. When he landed his army on the border at the beginning of May, the storage places were not prepared and he had to arrange them. Likewise, the shortage of food and ammunition temporarily halted Field Marshal Hadik, commanding the one hundred thousand strong army in Syrmia and Banat. At the end of June, he managed to encamp in Weiskirchen and began the siege of Semendria (Smederevo). As the Turks appeared in greater numbers in Wallachia and there was a worry that they might try to break into Transylvania, Hadik sent there several regiments of cavalry and infantry. In the summary, the publisher of "Pamietnik" writes that the grand vizier's plans were not yet known. He was stationed with his army by the Danube near Silistra, posing a threat to the imperial army in Banat and Transylvania, and to the Russians in Moldavia and Bessarabia. He awaited Selim III's instructions. The sultan recalled the kapudan pasha from his office and made him the serasker of Izmail instead. Having been given eighty thousand men, the serasker was ordered to recapture the Ochakiv. The sultan wanted to send half a million soldiers to the battlefield; yet, the food shortages made it difficult to recruit so many men ${ }^{24}$.

In the July issue, Switkowski reports on the further activity of the imperial army. Field Marshal Laudon abandoned the plan of seizing the Cetin castle and turned to Sclavonia with the intention of taking the Turkish Gradiška (Berbir) in possession. On 20 June, the army and artillery gathered near Old Gradiška (the Austrian side). General of the Artillery Johann Theodor von Rouvroy ${ }^{25}$ immediately prepared the cannons for the crossing of Sava. The Austrians noticed that on the other side of the river the Bosnians started gathering and might set up a camp in front of Gradiška, making it difficult for the troops to pass. In anticipation of their actions, Laudon hurriedly ordered to build a bridge over the river, and on the night of June 23 , he crossed it with his army. He set up his camp in a way that its one wing was on the bank of Sava and the other by the river

\footnotetext{
${ }^{24}$ PHPE, June 1789, pp. 628-632, p. 646.

${ }^{25}$ See C. von Wurzbach, op. cit., vol. XXVII, Wien 1874, pp. 175-177.
} 
Verbaska, while the remaining part of the troops was surrounding the fortress. At night, the Austrians arranged the batteries and in the morning they began building first sconces. Every day, the batteries were set closer and closer to the enemy. Laudon tried to act slowly and with caution since he had only fifteen thousand soldiers, whereas Bosnians counted twice as many. What is more, the relief was expected to arrive. The Austrian commander's foresight was also manifested in other actions: "he did not order to surround the fortress tightly on all sides, but left the passage on the side of a great forest, not to drive the garrison to despair, which makes the Turks so ferocious and almost invincible"26. Soon, the employed tactic bore fruit. After several days of the fortress being continuously sprayed with cannonballs, fireballs and gunpowder bags and the expected relief did not come, on July 8, the Turks left Gradiška and escaped to the woods. The Austrians entered the abandoned fortress the following day. In the storage place, they found thirty-five metal and four iron cannons, and a large amount of ammunition. Joseph II was exhilarated by the news of seizing Berbir, and even more by the fact that it was achieved at such a low cost. No more than thirty-eight soldiers and three workers were killed in the siege, and one hundred and thirty-three people were wounded ${ }^{27}$.

Meanwhile, the imperial army remained idle. Shortly after arriving at Banat, Field Marshal Hadik came down with a fever. For the time, General François Sébastien de Croix, Count of Clerfayt took command $^{28}$. The Turkish camp was not undertaking any major operations either since the grand vizier was relieved of his position and Cenaze Hasan Pasha, the serasker of Vidin, was appointed for the position instead. This way, new commanders-in-chief were assigned to the ground army and the navy. Switkowski suspects that the kapudan pasha and the grand vizier were recalled to Constantinople for they were proponents of waging war. At the same time, Selim III, who took the throne with a firm resolution to continue the war until it is finally settled, began to lean towards peace. In the whole Asia the prices were elevated, and there was a shortage of food in the capital

26 PHPE, July 1789, pp. 713-714.

${ }^{27}$ Ibidem, pp. 711-714, 744-745. For more on the subject, see F. Ta u b m a n n, Vita e fatti eroici Barone Gedeone di Laudon, tradotta la prima volta dal tedesco, part 1, Firenze 1790, pp. 18-36; G.B. Malles o n, Loudon: A Sketch Of The Military Life Of Gideon Ernest, Freiherr Von Loudon, Sometimes Generalissimo Of The Austrian Forces, London 1884, pp. 223-226.

${ }^{28}$ See J. Hirtenfeld, op. cit., pp. 284-287. 
itself, Bulgaria and Rumelia. In addition, the operations of Russian corsairs made it difficult to supply the army stationed by the Danube river. The fleet would have to be sent in to restore the maritime transport on the Black Sea. Nonetheless, the sultan was not willing to do so for fear of his fleet being defeated like in the previous year, and the faith of Constantinople would be sealed ${ }^{29}$.

Then, why did the Austrian and Russian armies not use opportunity of the Porte's inactivity and did not move into the Wallachian lands? The reason for this was hunger and the scarcity of provisions. It was extremely challenging and expensive to deliver food over 40-50 miles, and the Turks applied the scorched-earth tactics in territories that they had to surrender to the enemy. "In the whole Moldavia, no bread, crops, straw nor hay are to be found. All the fields are ravaged or abandoned. The best portion of farmers left in different directions to earn a crust", describes Switkowski ${ }^{30}$. As for the Russian troops, Potemkin was to guard Ochakiv with his seventy thousand soldiers, while Prince Repnin and the rest of the army were preparing to attack Bender ${ }^{31}$.

In August, 1789, a comprehensive article on the warfare in the East appeared in "Pamiętnik". It was reported that, in the given month, the main imperial army had not left the camp yet. Seeing as his health was deteriorating, the aged Field Marshal Hadik relinquished the highest command and passed it on Laudon, which caused a stir in the Austrian camp. "Heavy artillery from Petrovaradin and Vienna were sent down the Danube river to Semlin. Several thousand of assault ladders were brought, loads of bombs and large cannonballs were packed, and the flotilla loaded with heavy artillery was propelled to Semlin", as written in "Pamiętnik" ${ }^{32}$. Shortly afterwards, the news spread among soldiers that once Laudon arrives, the army would be crossing the river and the siege of Belgrade would begin.

Meanwhile, using the inactivity of the Austrian army in Banat and Syrmia, the Turks made their way to Transylvania and Moldavia. The grand vizier commanded forty thousand soldiers to cross the Danube, where they joined forces with the army of Nicholas Mavrogenes, the hospodar of Wallachia. The created army was split into two parts,

\footnotetext{
${ }^{29}$ PHPE, July 1789, pp. 716-718.

30 Ibidem, p. 719.

${ }^{31}$ Ibidem, pp. 718-721.

32 PHPE, August 1789, p. 829.
} 
one of which was to enter Transylvania and the other to fight against Coburg and the Russian troops in Moldavia. On July 15, eight thousand and five hundred Turks moved from Milui to the Tömes Trail in Transylvania and charged at the sconce in Prödial, manned by three infantry companies under the command of Major Layriz and equipped with three cannons. A few hours of fighting resulted in considerable losses; the Turks were repelled and forced to retreat. On August 4, another Ottoman unit of fourteen thousand men attempted to enter Banat through the Božava Trail. The Turks assaulted the Austrians encamped near Mehadia; yet, they were beaten ${ }^{33}$.

These small defeats merely foreshadowed the greater misfortunes that befell the Ottomans the same month in Muntenia. Having received the news that Mavrogenes and his troops were approaching the frontiers of Muntenia and that there were already twenty thousand Turks near Focssani, Prince Coburg made a proposal to General Alexander Suvorov, who was operating nearby, to join forces and strike the Turkish army before they make the first move. Answering the call, Suvorov's division (six thousand soldiers) set off on a brisk march and within 24 hours they covered the 10-mile distance from Bârlad to Adjud, where the Austrians camped. At 11 at night on July 28, the Russians joined Coburg's corps (fifteen thousand soldiers). The next day, the armies were resting, while three bridges on the Trotus river were erected, the first of which was guarded by Colonel Karaiczay, while the other two by Colonel Samuel von Kepiro $^{34}$ with two hussar divisions and one infantry battalion. The two commanders agreed on the following tactical formation: the imperial corps stood on the right with five battalions in the front line and four in the next. Each battalion was forming a quadrilateral and was equipped with five cannons. The artillery was placed between the battalions, while the horsemen followed the infantry in the third line. The Russian infantry, forming three quadrilaterals in the first line and two quadrilaterals in the second line, stood on the left. The Russian cavalry was placed in the third line, as in the Austrian troops. A small division of Colonel Karaiczay took up the position between the Russians and Austrians, whereas the Arnauts (Albanians) followed the cavalry ${ }^{35}$.

33 Ibidem, pp. 828-833.

${ }^{34}$ C. von Wurzbach, op. cit., vol. XI, Wien 1864, p. 169.

35 PHPE, August 1789, pp. 833-836. Walerian Kalinka (op. cit., p. 475) states that Coburg's corps numbered eighteen thousand soldiers. According to Andrzej 
At 3 in the morning on July 30, the allied troops set off in three columns, crossed the river Trotuş and made their way to Călimăneşti. During the march, Colonel Karaiczay led the vanguard in front of the Russians, while Colonel Kepiro covered the other two columns with his cavalry. Near Călimăneşti, the army stopped in battle formation, but as soon as the horses and people took some rest, they moved to Mărăşeşti. In the evening of July 30, the Austro-Russian army moved further, but only in two columns, one of which was covered by Colonel Karaiczay's cavalry and the other by Kepiro. Shortly before they started marching, the Russian Cossacks informed about an incoming Turkish patrol (three thousand soldiers) followed by Osman Pasha with a seven thousand strong unit. In addition to Karaiczay's division, Suvorov sent in one thousand and five hundred Cossacks and Arnauts. As soon as the Turks saw the Cossacks, they attacked and dispersed them in all directions. But Major Michael Kienmayer ${ }^{36}$, the commander of the Austrian regiment, despite being outnumbered, charged at the Turks and forced them to flee. Then, he ventured to the Putna River, forced Osman Pasha out of the camp, and burnt the camp to the ground.

Meanwhile, the allied Austro-Russian army continued the march. They reached the Putna River and build a bridge over it, which Colonel Karaiczay covered with his horsemen. The moment the first three floats landed on the water, the Turks appeared on the other side of the river. The Ottomans hoped to prevent the crossing but were put to flight by the cannonballs fired from two places. The construction continued unobstructed. A sudden overflow of the river made it impossible to build the second bridge. Thus, in the morning of July 31, the whole army had to cross marching in one column. The Ottomans again came to the river. They charged at the vanguard of Cossacks and Arnauts and scattered them. They attacked Suvorov, but failed. Although the allied troops were already marching for 18 hours, they traversed the terrain overgrown with bushes and thorns, "and when the horses were unable to pull the cannons through the thicket, the soldiers replaced them..."37. Once in Focşani, where Gazi Hasan Pasha was stationed, they stroke.

Andrusiewicz, he had under his command twelve thousand soldiers and Suvorov, six thousand. See id e m, Katarzyna Wielka. Prawda i mit, Warszawa 2012, p. 495.

${ }^{36}$ J. Hirtenfeld, op. cit., p. 268.

37 PHPE, August 1789, p. 842. 
The imperial army from the right wing began the attack. A Karl Schröder battalion under the command of Colonel Karl Auersperg ${ }^{38}$ pushed forward, killing the Turks with cannons. The Austrian cavalry approached the left flank of the enemy and charged the horsemen so violently that they immediately pulled back and fled from Focssani. Other three hussar divisions of the emperor attacked the janissaries in front of them with bare backswords, and made them flee and take refuge in the nearby St. Samuel monastery, just as the sipahis. At the same time, the Russians and Karaiczay's unit crushed the right wing where the enemy placed sconces. The commander of the Karl Schröder battalion attempted to capture the monastery in which janissaries were hiding, but died while trying to force the gate open. Soon, Prince Coburg with a volunteers battalion arrived at the monastery, pulling the cannons. The Austrians forced the walls of the monastery and stormed inside, slaying all the Turks. The rest of Gazi Hasan's army (over thirty thousand soldiers) was scattered, leaving the whole camp, artillery and wellstocked magazines to the enemy. At least one thousand Turkish soldiers were killed and ninety-six were captured. Sixteen banners and ten cannons were taken. On the same day (August 1), the Austrians seized more than one hundred carts, which were carrying food and ammunition from Brăila to the Turkish camp. After the battle, General Suvorov returned to his former position in Moldavia and Coburg entered the Wallachian territory. Mavrogenes and Serasker Dervish Mehmed Pasha gathered back the Turkish soldiers. The two leaders set up a camp again six miles from Focşani, but this time without tents, carts or warehouses ${ }^{39}$.

38 See J. Hirtenfeld, op. cit., pp. 282-283.

39 PHPE, August 1789, pp. 837-845. See F. Taubmann, op. cit., pp. 47-50; A. Andrusiewicz, op. cit., p. 495; S.S. Montefiore, Potiomkin, książe książat, Warszawa 2000, p. 497; idem, Katarzyna Wielka i Potiomkin, Warszawa 2013, p. 525 (in both of his works, Montefiore states that one thousand and five hundred Turkish soldiers died in the battle); I. de Madariaga, Russia in the Age of Catherine the Great, London 1981, p. 409 (it informs that Prince Coburg's corps consisted of eighteen thousand soldiers, i.e. three thousand more than given in Siwitkowski's journal); and F. Anthing, History of the campaigns of Count Alexander Suworow Rymnikski, field-marshal-general in the service of His Imperial Majesty, the Emperor of all the Russians: with a preliminary sketch of his private life and character, vol. II, London 1799, pp. [55-71] (here, it is mentioned as well that the Austrian army numbered eighteen thousand, while the Russian seven thousand. Turkish losses amounted to two thousand killed and approx. three hundred taken captive). 
"The last month was bad for Turkey, but this one was even worse", writes Switkowski in the September issue ${ }^{40}$, describing the eastern theatre of operations. The editor of "Pamiettnik" reports that after the battle of Focssani and Czernek (August 4), Turkey decided to try their luck in Banat. The troop of six thousand men broke through from the side of Orşova and set up a camp near Mehadia. General Clerfayt, who was a commander in the area, rushed at the Ottomans, defeated them and drove them high into the mountains (August 28). Meanwhile, the main imperial army massed near Semlin. On September 3, Field Marshal Laudon arrived, followed by Archduke Francis the next day. The siege of Belgrade was planned. Laudon had at his disposal: fifty thousand soldiers, seven hundred heavy guns, a multitude of ammunition and bombs of different caliber, one hundred and forty mortars, one hundred and fifty armed ships, and ten thousand people for building sconces. When the whole army gathered in the camp, the General of the Artillery, Count Karl Clemens Pellegrini ${ }^{41}$, was entrusted with the supervision of sconces, building up the batteries and mounting cannons over them, while General Johann Theodor von Rouvroy was responsible for the bombing. On September 12, once the construction of bridge was completed, forty thousand infantry men and nine thousand riders crossed the Sava river. The next day, the Austrians surrounded the fort and began to install the batteries, placing them at the maximum of nine hundred paces, Clerfayt's corps remained within the area. It was meant to repel the attack of Abda Pasha, the former commander of Belgrade, who was approaching with forty thousand soldiers to relieve the besieged city. For two days, Laudon tirelessly tended to all the preparations and hardly ever dismounted his horse. Switkowski writes: "Whereas the Turks, having only fifteen thousand men for the defense, instead of preventing the crossing and building bridges, instead of disturbing the construction of batteries at night, they are praying and are in mosques and entrust their fortress to the prophet. And it wasn't until the $14^{\text {th }}$ day that they started to intervene with the mounting of batteries by the mouth of Sava, but they had been already finished and were already setting the outskirts of the city on fire"42. The Turks

\footnotetext{
40 PHPE, September 1789, p. 944.

${ }^{41}$ General Karl Clemens, count Pellegrini died in Vienna on November 28, 1796. See C. von Wurzbach, op. cit., vol. XXI, Wien 1870, pp. 440-443.

${ }^{42}$ PHPE, September 1789, pp. 949-950.
} 
were not taking action in other areas either. Their fleet was stationed calmly near Ochakiv, the serasker in Izmail, and the grand vizier in Wallachia, hoping to stop the advance of Repnin's, Suvorov's and Coburg's army ${ }^{43}$.

The next article treating on the eastern war was published in October 1789. The priest continued with the story of the siege and occupation of Belgrade, and discussed the events taking place in Wallachia. At 10 in the morning, on September 30, the assault on Belgrade was launched. The troops participating in the attack were divided into four columns. The Austrians managed to occupy the outskirts and force the Turks to flee to the castle. Laudon demanded the surrender of the fortress. Osman Pasha, the chief of the Turkish garrison, responded with a cannonade. During the night of October 5, the Austrian commander-in-chief ordered to erect new batteries. The next day, they opened fire, which set several parts of the city ablaze. Around noon, the Turkish pasha sent a letter requesting to suspend hostilities for the next fifteen days. Laudon commanded to spray the fortress with bombs and fireballs again. The city was under fire the whole night, inflicting heavy losses on the Turks (one thousand and two hundred killed). On October 8, Osman Pasha signed the terms of surrender. The garrison was allowed to leave Belgrade with all its possessions, leaving behind the cannons, ammunition, forage for the horses and chaika boats. The Austrians escorted the Turkish soldiers to Orşova. The equipment and food of civilians was allowed to be sold. The Jews, Christians and renegades could leave the fortress together with the Turks. Deserters and Austrian prisoners were turned over to the winners. It was forbidden for the soldiers to approach or have anything to do with Turkish women. During the surrender, the Turkish garrison consisted of seven thousand men, out of whom one thousand were wounded. The winners captured considerable war booty: four hundred guns of various caliber, six thousand cwt. of gunpowder, and a large number of bullets and different ammunition. It constituted a first major victory for the imperial army. The Austrians lost only about five hundred men, and seven hundred were wounded. "It is hard to describe how this victory gladdened the emperor. Having won Belgrade, he became again the lord of the whole Serbia, which

${ }^{43}$ Ibidem, pp. 944-950. See F. Taubmann, op. cit., pp. 65-72; G.B. Malles o n, op. cit., pp. 227-229. 
had been taken away from the Austrian House in 1739", reports Świtkowski ${ }^{44}$.

Next, the article provides an account of the Battle of Râmnicu Sărat, also known as the Battle of Mărtinessti. After the defeat in the battle of Focşani, Grand Vizier Rudschuk Hassan, the successor of Yusuf Pasha, crossed the Danube with an army of one hundred thousand soldiers (mostly cavalry) and set up a camp near Galati. He was planning to join forces with Mavrogenes in order to finally crush Coburg's corps. The Austrian commander found out about his intentions from grand vizier's letter which the imperial hussars intercepted. He asked for the aid of Suvorov. The latter immediately gathered his division between the rivers of Prut and Seret and issued an order to march. On September 21, the Russians joined the Austrians operating in the region of Focssani. The following day, the allied troops crossed the Râmna river. The Russian corps, reinforced with two divisions of the imperial hussars, headed towards Mavrogenes' camp near Tyrgukukuli (Tyrgu-Kukuli), whereas the Austrians marched towards the Râmnicu Sărat river and lined in front of the grand vizier's camp. This way, Coburg's troops kept in contact with the Suvorov's unit. At daybreak, the Turks noticed the Russian army and charged at them with great force. The Russians resisted the violent attack and put the enemy to flight. The grand vizier sent eighteen thousand horsemen to aid Mavrogenes. The Turkish cavalry stroke the Russian left wing, but Coburg assisted Suvorov on the right. The Turks were repulsed and forced to withdraw. In the meantime, the rest of the imperial corps broke through the bushes and emerged, facing the grand vizier's army ${ }^{45}$.

All the Turkish infantry, consisting of forty thousand janissaries, was positioned in front of the forest that was separating the two camps. There were trenches dug in front, and the cavalry was guarding the left and right side of the forest. The Turks fired cannons and hit the entire front of the allied enemy troops. They also made an attempt to encircle the Russian soldiers grouped on the left flank, but without success. The grand vizier sent a few thousand horse-

${ }^{44}$ PHPE, October 1789, pp. 1037-1043 (quoted on pp. 1042-1043). For more information on the siege and occupation of Belgrade, see F. Taubmann, op. cit., pp. 73-79, 109-122; G.B. Malle s o n, op. cit., pp. 230-232. Also see W. Kalin ka, op. cit., p. 476.

45 PHPE, October 1789, pp. 1043-1048. 
men with six cannons against the right flank of the allied army, where General Karaiczay's brigade was positioned. Even though the Turks carried out the attack seven times, they were repelled by Karaiczay, with the helped of Suvorov. The defeated sipahis withdrew to the trenches. The Austro-Russian troops received an order to form a semicircle and march on the enemy, which was greeted with a loud cheer. During this attack as well as all throughout the whole battle, both commanders and other generals were leading at the head of the army. The Turks fired their cannons and rifles. To minimize the loss of men, the leaders of the allied army sent their cavalry against the Turkish infantry. The Ottomans were dispersed. The cavalry was followed by the infantry, which rushed to the trenches, took control of the cannons and forced the Turks to flee into the forest. It tipped the balance in favor of the united army. Still, there was a risk that the beaten and scattered Turks will gather and try to defend themselves in the camp with sconces near Râmnicu Sărat, and thus, had to be followed. The Turkish soldiers, however, saw that the enemy is chasing them and abandoned also the other camp, leaving all the artillery, ammunition, tents and equipment behind. The Austrians found in the waters of Râmnicu Sărat more than four thousand wagons, many cannons and mortars, carts with ammunition, gun barrels or rice, horses, camels, buffalos and sheep "so mixed up that it created a sort of a dam on the river". According to accounts of the captured Turks, before the battle, the army of the grand vizier numbered one hundred thousand soldiers, which was five times the size of the Austro-Russian troops. The battle began at sunrise and lasted almost until the sunset, that is eleven hours, with continuous fire. About four thousand Turks were killed on the battlefield, but only thirty-nine were taken into captivity as the Ottoman soldiers preferred to die than to seek pardon ${ }^{46}$.

${ }^{46}$ Ibidem, pp. 1049-1054. For more on the subject, see F. Ta u b m a n n, op. cit., pp. 50-59; F. Anthing, op. cit., pp. [79-107]. In the last position, it is quoted that the casualties on the Turkish side amounted to ten thousand soldiers: five thousand were killed in the battle, two thousand were killed in the forest or died of wounds, and three thousand drowned in the waters of Râmnicul Sărat. In his report sent to the sultan, the grand vizier assessed the losses at twenty thousand men, including deserters. Losses of the united armies were small. The Austrians had one hundred and fifteen dead and three hundred wounded, the Russians, only fifty-seven dead and one hundred and ten wounded. Alco see S.S. Mon- 
In another area of the front (Wallachia), Prince Friedrich Wilhelm von Hohenlohe-Kirchberg ${ }^{47}$ led six thousand soldiers against the camp of Kara Mustafa Pasha. According to Switkowski: "Even though the Turks demonstrated outstanding gallantry and each men fought for two, they were defeated and dispersed, leaving one thousand two hundred soldiers and six cannons on the battlefield" ${ }^{\prime 8}$. The Austrians lost six hundred soldiers in the two battles. The Russians also enjoyed notable success. Suvorov defeated the Turkish corps commanded by Gazi Hasan, the former kapudan pasha. What is more, he besieged the fortress Izmail in the northern part of the Danube delta and took it by storm $^{49}$.

In the November issue, the editor of "Pamiętnik" reports on increased activity of the Russians at the southern front. By the end of August 1789, Prince Potemkin camped with the main army in Ochakiv, ready to defend the fortress that had been seized with

tefiore, Potiomkin..., p. 499; idem, Katarzyna Wielka i Potiomkin..., pp. 526527 (the author states that Turkey lost fifteen thousand soldiers in the battle); I. de Madariaga, op. cit., p. 409; and Erläuterter Plan von der berühmten Schlacht bei Martinjestie in der Wallachey: in welcher unter den Befehlen sr. Durchlaucht des Herzogs Friedrich Josias von Sachsenkoburg, k.k. Generals der Kavallerie (nunmehrigen Feldmarschalls,) und des militärischen Theresienordens Großkreuz, der Großvezier mit 100000 seiner besten Truppen am 22. Sept. 1789 entscheidend geschlagen wurde, Prag 1789, pp. 5-24. It should be added that in recognition of his merits in the battle, the empress conferred a victory title "Rymniksky" upon Suvorov. She awarded him the first-class Order of Saint George decorated with diamonds, gave him a sword with the inscription: "the grand vizier's slayers", also with diamonds (the value of both gifts amounted to sixty thousand rubles), and promoted him to lieutenant-colonel of the Preobrazhensky regiment, while Emperor Joseph II made him a count. Also, the officers and soldiers of both corps were properly rewarded. The former received promotion and decorations, and the latter, monetary rewards. Those who stood out during the battle were awarded a medal with the inscription "Râmnicul Sărat". See F. Anthing, op. cit., pp. [110-111]; A. Andrusiewicz, op. cit., p. 497; S.S. Montefiore, Potiomkin..., p. 501; id em, Katarzyna Wielka i Potiomkin..., p. 529.

47 See Oesterreichisches Militär-Konversations-Lexikon. Unter Mitwirkung mehrerer Offiziere der k.k. Armee, redigirt und hrsg. von J. Hirtenfeld, Bd. III (H-Kulm), Wien 1852, pp. 248-249.

48 PHPE, October 1789, p. 1054. See W. Kalinka, op. cit., p. 475; F. Taubmann, op. cit., pp. 46-47.

49 PHPE, October 1789 , p. 1054. The news about the seizure of the Izmail fortress was premature. The Russians took it by storm after several months of siege on December 11 (22), 1790. See A. Andrusiewicz, op. cit., pp. 496-497; W.S. Serc zy k, Katarzyna II carowa Rosji, Wrocław 1989, p. 265; Z. Ry n i ew i c z, Leksykon bitew świata, Warszawa 2008, p. 228. 
such strenuous effort. But seeing as that the Turkish fleet accomplished little in the area and returned to Varna, he divided his army in two. With the first, he marched on Bender with the intention of seizing the fortress. The other part, under the command of Prince Repnin, was sent against the incoming serasker, with whom they clashed on September 20. The Turkish troops, "more frightened than damaged", fled the Danube river, leaving all of Bessarabia to the enemy. Given a free hand, the Russians commenced with besieging the Danube fortresses. They tightened the circle around Bender, where the generalissimo left some of the soldiers. Then, with the remaining troops, he headed towards Akkerman. In addition to being well-fortified and equipped with different sorts of ammunition, the fortress was important for its strategic location (by the sea and in the mouth of the Dniester). On October 11, the Russians took the fortress incurring no casualties and almost without a fight. They also overtook cannons, fifty-one from the ramparts and thirty-seven from the warships. A bit earlier, the Russian troops seized the Chodshabo castle ${ }^{50}$ and stormed Palanca, next to Akkerman ${ }^{51}$.

Having gotten rid of the enemy in the coastal areas, Potemkin moved to Bender. The priest-editor writes: "In any other situation, a numerous garrison and powerful fortifications would make any attempt to siege and capture the fortress incredibly difficult and would lead to bloodshed. But now that the Turkish troops were defeated and spread, and the commander knew that no relief would arrive and his people were not eager to defend themselves, he surrendered the fortress on November 5 . Together with his garrison, he was allowed to leave for Kiliya or Silistra"52. The Russians released eight thousand soldiers and occupied the city of thirty thousand inhabitants. Inside, they found three hundred and sixty cannons of gunmetal and forty of iron, as well as ammunition and food. Over two thousand cavalry horses were captured. On that bank of the Danube river, Turkey had nothing left but Kiliya ${ }^{53}$.

50 It took place on October 4, 1789. See Lettres à Monsieur le comte de $B^{* * *}$, sur la révolution arrivée en 1789, sous le règne de Louis XVI, avec des Notes sur les Ministres et autres gens en place qui, depuis le regne de Louis XV, ont donné lieu à cette Révolution mémorable, par des déprédations ou des abus d'autorité, ed. par chez les principaux libraires, vol. IV, Londres-Paris 1789, p. (284).

51 PHPE, November 1789, pp. 1116-1118.

52 Ibidem, pp. 1118-1119.

53 Ibidem. See W. Kalinka, op. cit., p. 495; S.S. Montefiore, Potiomkin..., pp. 499-500; idem, Katarzyna Wielka i Potiomkin..., p. 527; J.T. Alexander, 
While the Russians were overrunning Bessarabia and Budjak, the imperial army was engaged in conquering Serbia and Wallachia. Once Belgrade was seized, Field Marshal Laudon aimed at Orşova, which was located on the Danube island near Mehadia, between Banat, Serbia and Wallachia, and which was a gate to these three provinces. Laudon ordered General Ludwig Wilhelm Wartensleben ${ }^{54}$, the commanding officer of the army in Banat, to seize the fortress. After a demanding march in the mountainous and muddy terrain, on October 24, Wartensleben's corps reached Orşova and immediately took up the adjoining mountain of Allion. Two officers were sent to the commander with a demand to surrender the castle. Within 24 hours, the Turkish pasha responded in writing that he was ready to fight till the bitter end. On October 26, the Austrians began a siege of the fortress. In order to cut off the supply of food from nearby Kladovo, General Domenico Tomiotti de Fabris di Cassano ${ }^{55}$ crossed the Danube and forced the garrison of the town (five hundred soldiers) to give in (November 6). Apart from Kladovo, the Austrians seized "beautiful and still intact in this war" district of Kraina, which consisted of approx. one hundred and fifty towns and villages. Prince F.W. von Hohenlohe-Kirchberg, on the other hand, entered Wallachia and took Craiova. The approaching winter made it impossible for the troops to operate in Serbia. Therefore, the imperial army lined up between Zvornik and Jagodina, along the Great Morava River. Coburg quartered his troops in Bucharest. For the Austrians, the campaign of 1789 came to an end. The Emperor was overjoyed with their achievements. He promoted Coburg to the rank of Field Marshal, awarded him with a war cross and gave him a palace in Vienna. Whereas Catherine II, who already had gifted the general an expensive snuff-box after the battle of Focşani, wrote to him regarding his victory in Râmnicu Sărat: "for the first time since she became an empress, she was under an obligation to reward such exceptional merits of a prince; for this reason, she declared that she would at least make an attempt to express her profound gratitude"56.

Catherine the Great. Life and Legend, New York 1989, p. 279; I. de Madariaga, op. cit., p. 409 (the source indicates that the Turkish garrison numbered twenty thousand).

${ }^{54}$ See J. Hirtenfeld, op. cit., pp. 280-282.

55 Oesterreichisches Militär-Konversations-Lexikon..., Bd. II (D-G), Wien 1852, pp. 268-269; J. Hirtenfeld, op. cit., pp. 107-108.

${ }^{56}$ PHPE, November 1789, pp. 1120-1127 (quoted on p. 1126). See F. Taubmann, op. cit., pp. 118-132, 138-142. 
As reported by Świtkowski in December 1789, the Austrians did not yet manage to storm Orşova, the walls of which "rise almost from the water itself", making the fortress difficult to conquer. Later, the author of "Pamiettnik" continues: "Few buildings that stand inside are made of concrete and so, the bombs have nothing to set ablaze, while the casemates, in which the garrison is hiding, are so well-constructed that even 100-pound bombs cannot penetrate it" ${ }^{27}$. Taking all this into consideration, Laudon turned the siege into a blockade, sent Archduke Francis back to Vienna, and headed to Bucharest to work out further operation plans with Coburg. Pressured with deteriorating health and the revolution in the Netherlands, Joseph II commanded Peter Philipp Herbert Freiherr von Rathkeal ${ }^{58}$ to go to Bucharest and negotiate a truce with the envoy of the Porte as soon as possible. Meanwhile, in Constantinople, Selim III received letters from his two commanders informing that the Turkish army does not wish to continue fighting the enemy. Saddened by the news, the sultan recalled the grand vizier from the office and appointed Gazi Hasan, the ex-kapudan pasha, for the position instead, ordering him to establish peace. The new grand vizier proposed an armistice agreement to Potemkin and Coburg. Nonetheless, the former stoutly declared that he would not lay down his arms until they signed a treaty. The peace-seeking emperor advised the Prince of Tauris not to impose too harsh conditions on the Porte. In the final part of the article, Switkowski states that the Vienna court was not so much concerned with gaining new territorial but rather with keeping the old ones ${ }^{59}$.

Switkowski returns to the topic of the campaign in the January issue of his journal. He made an attempt at making a balance of the military operations of the previous year, described the peace negotiations between the Porte and the empires, and discussed preparations for the new campaign. In Constantinople, the news of military defeats created quite a furor. The Imperial Council wanted to find out how eighteen thousand Austrians and Russians could have beaten the one hundred thousand strong army of the grand vizier. The sultan sent his trusted men to the battlefield so that they could report to him on the area, the position of the

57 PHPE, December 1789, p. 1242.

58 C. von Wurzbach, op. cit., vol. VIII, Wien 1862, pp. 352-357.

59 PHPE, December 1789, pp. 1242-1245. For more details on the siege and blockage of Orşova, see F. Taubman n, op. cit., pp. 132-137. 
commander-in-chief and the arrangement of the allied forces. As it was later assessed, the failure was mostly an outcome of the grand vizier's ineptitude and thus, he was relieved of his position. Also, to quieten the crowd, he was arrested and brought to the capital. Selim III was so thoroughly alarmed by a great defeat and disgrace after receiving the bad news that he spent the whole night writing a hatti-sheriff, in which he blamed the pashas for "the villainy while fighting the infidels", which put the whole nation and the Muslim faith in danger. He urged them to mobilize the forces and to go ahead with military preparations to make up for the failures. He also announced that in the spring, he would lead the army himself, and either take revenge or die alongside other Muslims on the battlefield. At first, sultan's resolution summoned the courage in Turkey. But when the news about the loss of Bender, Akkerman, and especially Belgrade reached them, the fear gripped the nation. The Imperial Council decided to end the war. When Bucharest was captured on December 8, Mavrogenes, the hospodar of Wallachia, sent a messenger to Potemkin, asking where and with whom the Porte could negotiate the conditions of peace. Serenissimus replied that he had already received the power of attorney from his empress and pointed to Jassy as a location for future negotiations. The grand vizier immediately sent there his reis efendi with a large retinue of Turkish noblemen. At the beginning of January 1790, Russian Ambassador Yakov Bulhakov, freed by the sultan from the Castle (Fortress) of the Seven Towers, arrived in the capital of Muntenia, while the emperor sent there Baron Franz Maria von Thugut ${ }^{60}$, and commanded Herbert to prepare for leaving. On January 13, Joseph II received a message from Potemkin that the reis efendi was seeking a six-month ceasefire, not peace, and that the Porte was demanding the return of all the lost lands. Therefore, Herbert remained in Vienna and a messenger was sent after Thugut, ordering him to go to Bucharest instead, where he was to reside as governor of Wallachia. Seeing that without sacrifice and losses of the gained lands peace would not be reached, the sultan decided to continue the war. He commanded the pashas to gather the troops in Adrianople for the spring and called up all men aged

${ }^{60}$ For more information on his person, see C. von Wurzbach, op. cit., vol. XLV, Wien 1882, pp. 1-6; K.A. Roider, Baron Thugut and Austria's response to the French Revolution, Princeton 1987. 
18-60. To fill up the treasury, he ordered to bring all the silvers to the $\min ^{61}$.

Later, the editor of "Pamiętnik" reports that in January 1790, some of the frosts eased off. The Turks tried to use the improvement of weather conditions to increase their military activity at the front. In Croatia, they charged twice at the imperial cordon in the area of Cetin, but they could not break through. At the same time, the pasha of Vidin rushed to rescue the besieged Orşova. Five thousand Ottoman soldiers attacked the less numerous Austrian army, killing one hundred men and forcing the rest to flee. Shortly afterwards, the Turks appeared at the walls of Kladovo, where the defeated imperial soldiers took shelter, and ordered them to give up the fortress. Its commander, Colonel Anton von Lipthay ${ }^{62}$, came out to the battleground with four battalions and eleven hussars wagons. The Ottomans stroke four times, but eventually, they were repulsed and forced to retreat. The pasha's unsuccessful relief, however, did not make the defenders of Orşova lay down their weapons.

At the end, Świtkowski writes: "It seems outlandish that after so many unhappy encounters with the enemy, the Turks have enough courage for the third campaign. But they do know what takes place in the Netherlands. A forthcoming alliance between Prussia and Poland is of no mystery to them. To all appearances, a few years of arrangements between England, Holland and Prussia are complete enough, and they will attempt to interfere with such a dreadful and successful alliance of the two empires so that it would not threaten the independence of the whole Europe"63. He further indicates that the alliance between France and Austria would be of no use to Joseph II. On the northern front, the situation was developing in favor of Turkey. Gustav III was preparing for a new campaign, mobilizing all the forces of his country. He wanted to deploy a seventy thousand strong ground army and a fleet of galleys which would be twice as large as in the previous year. The emperor's poor health had to entail certain delay "in planning and executing", while Laudon, Turkey's biggest fear, left for the Czech

${ }^{61}$ PHPE, January 1790, pp. 90-93. On the negotiations in Jassy, see S.S. M o ntefiore, Potiomkin..., p. 502, 511; id e m, Katarzyna Wielka i Potiomkin..., p. 530, pp. 539-540; I. de Madariaga, op. cit., p. 410.

${ }^{62}$ See J. Hirtenfeld, op. cit., pp. 243-244.

${ }^{63}$ PHPE, January 1790, p. 95. 
lands, where he was to assume command of the army. No wonder that, against all odds, the High Porte decided to chance their luck yet again in the upcoming campaign ${ }^{64}$.

Summing up the above considerations, it should be noted that the "Pamiętnik Historyczno-Polityczno-Ekonomiczny" was publishing fairly detailed monthly reports on the ongoing operations at the eastern front. It informed about the events occurring on the land and, to a lesser extent, on the sea, about the status and numbers of the fighting armies, gave an account of the most important battles as well as minor skirmishes. While the war in the initial phase (despite losing Ochakiv) turned out to be promising for the Turks, the campaign of 1789 resulted in failures. The Russians defeated them several times in the open field and seized their fortresses: Galați, Akkerman, and the most significant one, Bender. The Austrian ally of Catherine II was making progress in Serbia and Wallachia. The loss of Belgrade was particularly painful for the Porte as it had been in the hands of Turkey since the last war with Austria. Despite a popular belief that any commentary of the author constitutes a violation of journalist's reliability, Świtkowski sometimes voiced his own opinions, cleverly weaving them into the text or placing them in the footnotes. As a sympathizer of the pro-Turkish politics, he wrote about the Ottomans and the Ottoman Empire with fondness, praised the boldness and gallantry of a Turkish soldier, and tried to challenge and straighten out some ideas about Turkey which he considered erroneous.

\section{Bibliography}

\section{Printed sources}

Anthing F., History of the campaigns of Count Alexander Suworow Rymnikski, field-marshal-general in the service of His Imperial Majesty, the Emperor of all the Russias: with a preliminary sketch of his private life and character, vol. II, London 1799.

Erläuterter Plan von der berühmten Schlacht bei Martinjestie in der Wallachey: in welcher unter den Befehlen sr. Durchlaucht des Herzogs Friedrich Josias von Sachsenkoburg, k.k. Generals der Kavallerie (nunmehrigen Feldmarschalls,) und des militärischen Theresienordens Großkreuz, der Großvezier mit 100000 seiner besten Truppen am 22. Sept. 1789 entscheidend geschlagen wurde, Prag 1789.

${ }^{64}$ Ibidem, pp. 93-96. 
Hirtenfeld J., Der Militär-Maria-Theresien-Orden und seine Mitglieder: Nach authentischen quellin bearbeitet, Wien 1857.

Lettres à Monsieur le comte de $B^{* * *}$, sur la révolution arrivée en 1789 , sous le règne de Louis XVI, avec des Notes sur les Ministres et autres gens en place qui, depuis le regne de Louis $X V$, ont donné lieu à cette Révolution mémorable, par des déprédations ou des abus d'autorité, ed. par chez les principaux libraires, vol. IV, Londres-Paris 1789.

Oesterreichisches Militär-Konversations-Lexikon. Unter Mitwirkung mehrerer Offiziere der k.k. Armee, redigirt und hrsg. von J. Hirtenfeld, Bd. II (D-G), Wien 1852; Bd. III (H-Kulm), Wien 1852.

Taubmann F., Vita e fatti eroici Barone Gedeone di Laudon, tradotta la prima volta dal tedesco, parte 1, Firenze 1790.

\section{Press}

“Gazeta Warszawska” 1788.

"Pamiętnik Historyczno-Polityczno-Ekonomiczny” 1788-1790.

\section{STudies}

Aleksandrowska E., Świtkowski Piotr, [in:] Dawni pisarze polscy od poczatków piśmiennictwa do Młodej Polski. Przewodnik biograficzny i bibliograficzny, vol. IV (S-T), koordynacja całości R. Loth, Warszawa 2003, pp. 232-233.

Alexander J.T., Catherine the Great. Life and Legend, New York 1989.

Andrusiewicz A., Katarzyna Wielka. Prawda i mit, Warszawa 2012.

Bartoszewicz J., Gazeta księdza Łuskiny, [in:] idem, Znakomici mężowie Polscy w XVIII $w$., vol. I, Petersburg 1855, pp. 261-330.

Giełżyński W., Prasa warszawska 1661-1914, Warszawa 1962.

Gozdawa-Gołębiowski J., Wojny morskie 1775-1851, Warszawa 2001.

Homola-Dzikowska I., Pamiętnik Historyczno-Polityczny Piotra Świtkowskiego 17821792, Kraków 1960.

Kalinka W., Sejm Czteroletni, vol. I, Warszawa 1991.

Karkocha M., Obraz Francji $w$ dobie rewolucji na łamach prasy warszawskiej $z$ lat 1789-1794, Łódź 2011.

Karkocha M., Wojna rosyjsko-turecka na łamach "Pamiętnika Historyczno-Politycznego" (1787-1788), [in:] Sic erat in votis. Europa $i$ świat w czasach nowożytnych. Studia i szkice ofiarowane Profesorowi Zbigniewowi Anusikowi w sześćdziesiatą rocznicę urodzin, eds M. Karkocha, P. Robak, Łódź 2017, pp. 311-342.

Łojek J., Dziennikarze i prasa w Warszawie w XVIII wieku, Warszawa 1960.

Łojek J., "Gazeta Warszawska” księdza Euskiny (1774-1793), Warszawa 1959.

Łojek J., Historia prasy polskiej, Warszawa 1976.

Łossowska I., Piotr Świtkowski (1744-1793), [in:] Pisarze polskiego Oświecenia, eds T. Kostkiewiczowa, Z. Goliński, vol. II, Warszawa 1994, pp. 305-319. 
Madariaga I. de, Russia in the Age of Catherine the Great, London 1981.

Malleson G.B., Loudon: A Sketch Of The Military Life Of Gideon Ernest, Freiherr Von Loudon, Sometimes Generalissimo Of The Austrian Forces, London 1884.

Montefiore S.S., Katarzyna Wielka i Potiomkin, Warszawa 2013.

Montefiore S.S., Potiomkin, książe książąt, Warszawa 2000.

Morawski W., Szawłowska S., Wojny rosyjsko-tureckie od XVII do XX wieku, Warszawa 2006.

Roider K.A., Baron Thugut and Austria's response to the French Revolution, Princeton 1987.

Ryniewicz Z., Leksykon bitew świata, Warszawa 2008.

Serczyk W.S., Katarzyna II carowa Rosji, Wrocław 1989.

Wieczorkiewicz P.P., Historia wojen morskich. Wiek żagla, vol. I, Warszawa 1995.

Wurzbach C. von, Biographisches Lexikon des Kaiserthums Oesterreich, T. II, Wien 1857; T. VIII, Wien 1862; T. XI, Wien 1864; T. XIV, Wien 1865; T. XVI, Wien 1867; T. XXI, Wien 1870; T. XXVII, Wien 1874; T. XLV, Wien 1882.

Matgorzata Karkocha

\section{Wojna rosyjsko-turecka (kampania 1789 roku) w świetle doniesień „Pamiętnika Historyczno-Polityczno-Ekonomicznego”}

Przedmiotem artykułu jest wojna rosyjsko-turecka $z$ lat 1787-1792, a ściślej podstawie informacji publikowanych na łamach „Pamiętnika Historyczno-Polityczno-Ekonomicznego”. Pismo to ukazywało się w Warszawie w latach 17821792, a jego redaktorem i wydawca był ksiądz Piotr Świtkowski. Od początku wojny rosyjsko-tureckiej, do której w lutym 1788 r. przyłączyła się Austria jako sojusznik Katarzyny II, „Pamiętnik” zamieszczał periodyczne sprawozdania z działań na froncie tureckim. Opisywał najważniejsze bitwy, ale też mało istotne potyczki, informował o ruchach i stanie walczących armii, drukował etaty wojsk i wiadomości biograficzne o dowódcach. Świtkowski był zwolennikiem polityki protureckiej i jako taki $z$ sympatia wypowiadał się na temat Porty i jej mieszkańców, chwalił waleczność tureckiego żołnierza, pozytywnie odnosił się też do reform wojskowych przeprowadzanych $\mathrm{w}$ tym państwie.

Słowa kluczowe: wojna rosyjsko turecka 1787-1792, kampania 1789 roku, „Pamiętnik Historyczno-Polityczno-Ekonomiczny”, Piotr Świtkowski, prasa warszawska, XVIII wiek. 